\title{
Assessment of coarse and fine hand motor performance in asymptomatic subjects exposed to hand-arm vibration
}

\author{
Martin B. Popević1,2, Srđan M. Janković2, Srđan S. Borjanović ${ }^{1,2}$, Slavica R. Jovičić2 , Lazar R. \\ Tenjović ${ }^{3}$, Aleksandar P.S. Milovanović ${ }^{1,2}$, and Petar Bulat ${ }^{1,2}$ \\ Faculty of Medicine, University of Belgrade ${ }^{1}$, Serbian Institute for Occupational Health ${ }^{2}$, School of Philosophy, \\ Department of Psychology, University of Belgrade ${ }^{3}$ Belgrade, Serbia \\ Received in May 2013 \\ CrossChecked in May 2013 \\ Accepted in January 2014
}

\begin{abstract}
A frequently encountered exposure profile for hand-arm vibration in contemporary occupational setting comprises workers with a long history of intermittent exposure but without detectable signs of hand-arm vibration syndrome (HAVS). Yet, most of the published studies deal with developed HAVS cases, rarely discussing the biological processes that may be involved in degradation of manual dexterity and grip strength when it can be most beneficial - during the asymptomatic stage. In the present paper, a group of 31 male asymptomatic vibration-exposed workers (according to the Stockholm Workshop Scale) were compared against 30 male controls. They were tested using dynamometry and dexterimetry (modelling coarse and fine manual performance respectively) and cold provocation was done to detect possible differences in manual performance drop on these tests. The results showed reduced manual dexterity but no significant degradation in hand grip strength in the exposed subjects. This suggests that intermittent exposure profile and small cumulative vibration dose could only lead to a measurable deficit in manual dexterity but not hand grip strength even at non-negligible A(8) levels and long term exposures.
\end{abstract}

KEY WORDS: cold provocation; grip strength; manual dexterity; vibration exposure

The asymptomatic workers with intermittent handarm vibration (HAV) exposure receive little to no attention in the literature. They routinely pass the screening tests with $0 \mathrm{SN}, 0 \mathrm{~V}$ score according to the Stockholm Workshop Scale (1). Yet, the absence of symptoms in no way implies the absence of vibrationinduced damage, as the vibration energy is dissipated in tissues, producing not so easily observable effects. These changes in asymptomatic workers are subtle and the available literature on the risk of accidents at the workplace is scarce. The character of this risk, if existent, would likely depend on whether the changes influence the performance in work operations requiring coarse and/or fine manipulation. Usually, the same worker performs more than one task, using different tools and various levels of muscle strength and manual dexterity. In developed Hand-Arm Vibration Syndrome (HAVS) cases, the damage is clearly detectable. Prolonged exposure to handtransmitted vibration causes vascular, neural, and musculoskeletal disorders in the hand and arm. The most prominent is cold-induced vasospastic reaction in the hand with painful blanching of the fingers, known as Vibration White Finger (VWF) $(2,3)$. It is caused by the altered vascular response in people working with vibrating power tools (4) and is diagnosed using the cold provocation (CP) test (5). Long-term use of vibrating tools may also induce 
neural problems, resulting in impaired dexterity and fine manipulation ability, numbness, paresthesia, reduced tactile discrimination, and tendency to drop tools (6). The impaired manual dexterity may be associated with reduced sensory feedback and muscular dysfunction in the fingers and hands $(6,7)$. Hand muscle weakness, particularly affecting the long finger flexors and affecting grip strength was also found $(6,8,9)$.

There is ambiguous data in the literature regarding the development of vibration-induced changes: while some sources point to reversibility (10-13), others do not $(9,14,15)$. Some references suggest intermittency alone as a factor in reducing the extent of damage (16). Our pilot study analyses the differences in hand performance between the healthy subjects and those with the vibration exposure profile comprising workers that have a long history of intermittent vibration exposure, yet exhibit no detectable signs of HAVS.

\section{METHODS}

The sample was composed of 61 male subjects divided into two groups. The exposed group $(n=31)$ included subjects who had a history of at least five years of occupational exposure to hand-arm vibrations. They were chainsaw operators $(\mathrm{n}=19)$, chipper and grinder workers using pneumatic chipping hammers and hand-held rotary vibrating tools $(\mathrm{n}=6)$, and other workers operating similar devices $(n=6)$. They had no less than two, but no more than four months of effective exposure to vibration-inducing tools per year and no HAVS symptoms. Subjects with diabetes mellitus, cerebrovascular diseases, alcoholic neuropathies, cervical spondylosis, previous surgical treatment of nerves in the arm or injuries to upper extremities, and those receiving drug treatments for hypertension, were excluded. Thirty healthy men of similar age, who had never worked with hand-held vibrating tools, were selected for the control group $(n=30)$. The same exclusion criteria applied to them. The study was reviewed and approved by the Institute's review and ethics board, and was performed according to the Declaration of Helsinki. All participants gave their informed consent.

The basic characteristics of the subjects and their exposure data are shown in Table 1. A(8) values (daily vibration exposure value normalised to $8 \mathrm{~h}$ ), which is the standard metric used for assessing HAV exposure (17), pertain to the days when they were exposed to vibration at work. The difference between groups in mean age and number of smokers did not reach statistical significance.

The subjects were asked to refrain from smoking for one day before the tests. The tests were conducted in a room with controlled temperature and humidity. Temperature was maintained between $22{ }^{\circ} \mathrm{C}$ and $23{ }^{\circ} \mathrm{C}$ while the relative humidity was between $40 \%$ and $60 \%$. The pre-test acclimatisation period was $30 \mathrm{~min}$.

The assessments included hand performance as a coarse function (hand grip strength, estimated by dynamometry) and a fine function (manual dexterity, estimated by the pegboard test). Each participant was asked to perform a hand grip strength test followed immediately by the manual dexterity test. After that, they underwent cold provocation and then immediately repeated the grip strength and the manual dexterity tests under the same conditions. The cooling helped to correctly select asymptomatic subjects (any finger blanching was considered to be a symptom, thus all such subjects were excluded) and was also expected to increase the sensitivity of the tests, by inducing more pronounced vasoconstriction in vibrationexposed workers.

The hand grip strength test was performed by squeezing the calibrated hydraulic Jamar dynamometer with maximum strength of their dominant hand for $3 \mathrm{~s}$. In order to achieve maximum voluntary contraction, participants sat comfortably in a chair without armrests, with the shoulder adducted, the elbow flexed

Table 1 Characteristics of the subjects

\begin{tabular}{|c|c|c|c|c|c|c|c|c|}
\hline \multirow[t]{2}{*}{ Group } & \multirow[t]{2}{*}{$\mathbf{n}$} & \multicolumn{2}{|c|}{ Age (years) } & \multicolumn{2}{|c|}{$\begin{array}{c}\text { Exposure duration } \\
\text { (years) }\end{array}$} & \multicolumn{2}{|c|}{$\mathbf{A}(8)\left(\mathrm{m} \mathrm{s}^{-2}\right)$} & \multirow{2}{*}{$\begin{array}{c}\text { Current } \\
\text { smokers } \\
\text { (n) }\end{array}$} \\
\hline & & Mean & SD & Mean & SD & Mean & SD & \\
\hline Exposed & 31 & 43.84 & 7.98 & 17.3 & 9.1 & 2.17 & 1.12 & 21 \\
\hline Controls & 30 & 39.17 & 11.00 & - & - & - & - & 14 \\
\hline
\end{tabular}

A(8) - daily vibration exposure value normalised to $8 \mathrm{~h}$ 
at $90^{\circ}$ and the wrist in the neutral flexion-extension position (18). Following relaxation, the maximum strength during the three-second exertion was recorded. The DynPre was a pre-cooling, while DynPos was a post-cooling dynamometer reading in $\mathrm{kg}$.

For the manual dexterity test, a standardised pegboard was used. The participants picked up cylindrical pegs, one by one, from a plate using their dominant hand and inserted them one by one into the holes on the board (19). The number of inserted pegs in $30 \mathrm{~s}$ was recorded. DexScrPre was a pre-cooling, while DexScrPos was a post-cooling number of inserted pegs.

The cold provocation test was performed according to the following protocol. The subjects were instructed to immerse their dominant hand, up to the elbow, into stirred water, kept at $10^{\circ} \mathrm{C}$. The immersion duration was 5 min measured by the stopwatch (5). After cooling, the subjects pulled out their hand from the cold water, and water residue was removed using tissue paper. As much water as possible was removed by tapping for 3-4 s, without providing massage so as to avoid the stimulation of blood circulation.

The parameters used for statistical analyses were DynPre, DynPos, DexScrPre, and DexScrPos. To investigate the effects of cooling on coarse and fine hand performance in the control and exposed groups, two-way mixed ANOVA (with cooling as withinsubjects and group as between-subjects factor) was used. Since two variables (grip strength and pin insertion score) were measured under each of the two levels of within-subjects factor (before and after cooling), a doubly multivariate analysis was performed.
A significant effect of cooling on both grip strength and manual dexterity had to be demonstrated in order to consider the procedure valid. Besides the main effect of cooling, the group by cooling interaction was of interest: its significance would indicate that the groups differed in the magnitude of performance drop due to CP. In order to detect possible differences between groups before cooling, the additional statistical tests included comparisons of the DynPre parameter between the two groups, and of the DexScrPre parameter between the groups by two separate one-way univariate analyses of covariance (ANCOVA), using age as the covariate. To control the probability of Type I error in the analyses of covariance, we set in advance a $P$ value of 0.025 as the criterion for significance. Data analyses were done using SPSS ${ }^{\circledR} 15.0$.

\section{RESULTS}

The means and standard deviations of the dynamometry and manual dexterity test results, both pre- and post-cooling, are shown in Table 2.

Before univariate analyses we conducted a multivariate analysis with cooling and group as independent and grip strength and pin insertion score as dependent variables. Two-way mixed multivariate analysis of variance showed significant effects of cooling [Wilks' lambda $=0.27, \mathrm{~F}(2,58)=77.74$, $P<0.001]$ and group [Wilks' lambda $=0.72$, $\mathrm{F}(2,58)=11.25, P<0.001]$ but the group by cooling interaction was not significant [Wilks' lambda $=0.996$, $\mathrm{F}(2,58)=0.11, P=0.893]$.

Table 2 Results of dynamometry and manual dexterity tests - parameter means $(M)$ and standard deviations (SD)

\begin{tabular}{lcccc}
\hline \multirow{2}{*}{ Variables } & \multicolumn{3}{c}{ Exposed (n=31) } & \multicolumn{2}{c}{ Control (n=30) } \\
\cline { 2 - 5 } & M & SD & M & SD \\
\hline Pre-cooling grip strength (kg) & 49.52 & 9.21 & 52.50 & 7.45 \\
Post-cooling grip strength (kg) & 40.45 & 10.43 & 44.13 & 6.18 \\
\hline $\begin{array}{l}\text { Pre-cooling pin insertion score } \\
\text { DexScrPre (pins) }\end{array}$ & 14.39 & 2.11 & 16.63 & 1.79 \\
$\begin{array}{l}\text { Post-cooling pin insertion score } \\
\text { DexScrPos (pins) }\end{array}$ & 13.29 & 2.19 & 15.60 & 1.75 \\
\hline
\end{tabular}


As follow-up tests to multivariate analysis, separate univariate analyses were conducted on each dependent variable. The univariate two-way mixed ANOVAs (Table 3 ) showed a statistically significant effect of cooling on both grip strength and pin insertion score. The results confirmed a statistically significant drop in performance after cooling on both coarse and fine hand performance as described in literature (20) indicating a valid experimental procedure.

The group by cooling interaction was not significant, neither for grip strength, nor for pin insertion score. In that way, there was no evidence that groups differed in the hand motor performance drop due to cooling.

The main effect of group was significant for the pin insertion score, but not for grip strength. This means that the groups differed in fine motor performance while at the same time we did not find evidence for such difference between groups in coarse motor performance.

We also compared the groups on two variables: DynPre and DexScrPre using two separate univariate analyses of covariance, with age as a covariate. This was done in order to test whether the groups differed in hand performance regardless of cooling. To verify the assumption of homogeneity of the regression slope, preliminary analyses of covariance, that included age by group interaction in the model, were done. These analyses showed that the age by group interaction was not statistically significant, neither in the analysis with grip strength, nor for the pin insertion score, and that the condition of homogeneity of the regression slope was met. The results of the main analyses of covariance (Table 4) revealed that the covariate age was significantly related to both grip strength and the pin insertion score. There was also a significant effect of group on the pin insertion score after controlling for age. Adjusted mean on the pin insertion score for the controls was 16.47 (standard error $=0.34$ ) and for the exposed 14.55 (standard error $=0.34$ ). The effect of group on grip strength after controlling for age was not statistically significant.

\section{DISCUSSION}

Hand-arm vibration exposure over a period of time may degrade hand performance, which can be detected as reduced grip strength (9) or impaired manual dexterity $(6,7)$ representative of coarse and fine hand functions respectively. The present study dealt with workers exposed to intermittent vibration, asymptomatic with regard to HAVS according to the Stockholm Workshop Scale (1).

The results showed reduced manual dexterity, but no significant degradation in hand grip strength.

Manual dexterity loss is a known consequence of vibration exposure $(6,7,21,22)$. It results from

Table 3 The results of two-way mixed ANOVA for comparing the exposed $(n=31)$ and control $(n=30)$ groups on the pre-and post-cooling values of grip strength and pin insertion score

\begin{tabular}{llccccc}
\hline \multicolumn{1}{c}{ Analysis } & \multicolumn{1}{c}{ Effect } & $\begin{array}{c}\text { Mean } \\
\text { Square }\end{array}$ & F & df & $\boldsymbol{P}$ & $\begin{array}{c}\text { Partial } \\
\text { Grip strength }\end{array}$ \\
& Group & 338.689 & 2.68 & 1 & 0.107 & 0.04 \\
& Cooling & 2316.2 & $\mathbf{1 2 8 . 6 3}$ & 1 & $<\mathbf{0 . 0 0 1}$ & 0.69 \\
& Group by Cooling & 3.712 & 0.21 & 1 & 0.651 & 0.003 \\
& Error (cooling) & 18.007 & 59 & & & \\
& Error (group) & 126.47 & 59 & & & \\
\hline Pin insertion score & Group & 158.225 & $\mathbf{2 2 . 8 8}$ & 1 & $<\mathbf{0 . 0 0 1}$ & 0.28 \\
& Cooling & 34.59 & $\mathbf{3 9 . 3 7}$ & 1 & $<\mathbf{0 . 0 0 1}$ & 0.40 \\
& Group by Cooling & 0.031 & 0.04 & 1 & 0.852 & 0.001 \\
& Error (cooling) & 0.879 & 59 & & & \\
& Error (group) & 6.916 & 59 & & & \\
\hline
\end{tabular}


Table 4 The results of the analyses of covariances for comparing the exposed $(n=31)$ and control $(n=30)$ groups on grip strength (DynPre) and pin insertion score (DexScrPre) pre-cooling results with age as a covariate

\begin{tabular}{llccccc}
\multicolumn{1}{c}{ Analysis } & Effect & $\begin{array}{c}\text { Mean } \\
\text { Square }\end{array}$ & F & df & $\boldsymbol{P}$ & $\begin{array}{c}\text { Partial } \\
\boldsymbol{\eta}^{2}\end{array}$ \\
\hline $\begin{array}{l}\text { Analysis of covariance 1 } \\
\text { (dependent variable: DynPre) }\end{array}$ & Age & 413.09 & $\mathbf{6 . 4 1}$ & 1 & $\mathbf{0 . 0 1 4}$ & 0.10 \\
& Group & 41.25 & 0.64 & 1 & 0.427 & 0.01 \\
& Error & 64.49 & & 58 & & \\
\hline $\begin{array}{l}\text { Analysis of covariance 2 } \\
\text { (dependent variable: DexScrPre) }\end{array}$ & Age & 26.65 & $\mathbf{7 . 7 4}$ & 1 & $\mathbf{0 . 0 0 7}$ & 0.12 \\
& Group & 52.88 & $\mathbf{1 5 . 3 6}$ & 1 & $<\mathbf{0 . 0 0 1}$ & 0.21 \\
& Error & 3.44 & & 58 & & \\
\hline
\end{tabular}

reduced sensitivity in the extremities, in particular, from impaired sensory feedback from the mechanoreceptors and their afferent nerve fibres which are located in the (epi)dermal and subcutaneous tissues of the glabrous skin of the fingers and hands (6). The mechanoreceptors include Meissner's and Pacinian corpuscles and Merkel's disks reacting to strokes, vibration, and pressure respectively. The sensory feedback is transmitted to the spinal cord via fast A- $\beta$ sensory afferents. The superficial Merkel's disks and Meissner's corpuscles are innervated by slowly adapting type I afferents (SAI afferents) and so-called fast-adapting type I afferents (FAI afferents), respectively. The deeper Pacinian corpuscles are innervated by slowly adapting type II (SAII) afferents and fast-adapting type II (FAII) afferents $(23,24)$. Precise control for picking up objects requires exact sensory feedback from SAI afferents, and to a lesser extent FAI afferents (6). Vibration-exposed subjects often have slower digital sensory nerve conduction and damaged cutaneous perception of vibration, pain, and thermal and tactile perceptions $(25,26)$. Impaired tactile perception is caused by segmental breakdown and loss of myelin sheath in sensory A- $\beta$ nerve fibres transmitting signals from mechanoreceptors. This is the result of vibration energy transfer. The loss of saltatory conduction due to segmental demyelination leads to a decrease in conduction velocity and conduction block. While lesions are theoretically reversible, because Schwann cells make new myelin, in many cases, demyelination leads to a decreased number of myelinated nerve fibres in the fingers (27). It has been suggested that initial vibration-induced neurological symptoms are due to intraneural oedema and vasospasm of epineural blood vessels (2). These changes are followed by demyelination, perineural fibrosis and nerve fibre damage in the form of axonal atrophy and cell body degeneration $(14,28,29)$. The nerve pathology explains the common symptoms reported by vibration-exposed subjects: numbness, loss of dexterity, clumsiness and paraesthesia $(2,28)$.

Two phases of vibration-induced nerve injury were identified: the initial, reversible, with a rate of recovery dependent on the elimination of oedema from the nerve and the subsequent phase involving pathological changes with destruction of myelin sheath and axons and the disappearance of nerve fibres from mechanoreceptors (30). The elimination of oedema from the nerve occurs in periods without exposure. In the intermittent exposure profile these periods may be too short for intraneural pressure to return to normal. Hence incomplete recovery, in periods without exposure, may contribute to the reduction of manual dexterity (13).

Our findings are consistent with the results reported in other studies $(6,7,21,22)$ which found impairment to manual dexterity in groups of workers exposed to hand transmitted vibration. However, our findings could not be directly compared with these results as most of the published studies deal with developed HAVS cases $(6,7,31)$, rarely discussing the biological processes of damage/repair that are relevant for the 
observed decrease in manual dexterity, as an integrative measure of hand performance, especially when it can be most beneficial, i.e. during the asymptomatic stage.

The decreased grip strength has also been reported $(6,8,9)$. The pathohistological studies $(9,15,32)$ have shown that the thenar muscles undergo necrosis, fibrosis, and fibre-type regrouping. The changes suggest damage both to the muscles and nerve supply (15) and structural changes in the nerves proximal to the wrist (33). The observed misalignment of myofibrils could explain their inability to generate full voluntary muscle tension (9).

Manual dexterity relies on the integrity of mechanoreceptors and their afferent nerve fibres which provide an exact sensory feedback to control motion signals for precise finger movements. On the other hand, the pathophysiological mechanism for the reported reduction of grip force in vibration exposed subjects is unknown. Theoretically, muscular dysfunction may arise from direct injury to muscle tissue or due to lesions in afferent or efferent pathways (34). What is difficult to establish is whether this muscle damage and consequently diminished grip strength is directly due to mechanical injury in the contractile proteins of the muscle tissue or secondary to a deficient blood supply. It could also be a consequence of later developing damage of motor nerves innervating the hand muscles $(8,35)$.

In this study, no statistically significant decrease in grip strength was found. The intermittency of exposure and the small cumulative vibration dose may be involved in such an outcome. A plausible explanation could be that intermittency and low-level vibration exposure cause lesions in nerve fibres which provide sensory feedback for motion signals that control tasks requiring manual dexterity. On the other hand, equally well preserved neural feedback is not required to control raw grip force.

Although one could expect the vibration-exposed workers to have a more pronounced reaction to cold stress, CP produced no significant differences in performance drops on hand grip and manual dexterity tests between vibration-exposed and healthy subjects. Though the performance drops were always larger in subjects with vibration exposure history, the difference was not significant. Such results suggest that cold exposure (typical for outdoor workers) does not additionally impair manual performance in vibrationexposed subjects without HAVS symptoms. The intermittent exposure profile and small cumulative vibration dose might explain the absence of a more significant decrease in performance in the exposed group.

\section{CONCLUSIONS}

The present study found a statistically significant decrease in manual dexterity between healthy and vibration-exposed subjects. No degradation in hand grip strength was observed in those with the intermittent vibration-exposure profile but asymptomatic with regard to HAVS. This suggests that intermittent exposure profile and small cumulative vibration dose could only lead to a measurable deficit in manual dexterity but not hand grip strength even at non-negligible $\mathrm{A}(8)$ levels and long term exposures. The vibration-induced lesions of nerve fibres and/or mechanoreceptors, which provide sensory feedback for motion signals that control tasks requiring precise finger movements, could be responsible for the observed decrease in manual dexterity. However, such mechanism is not required for raw grip force.

Further studies, which would include a larger sample and pathohistological findings, are required to verify the observed results and explain why changes occur only in the fine but not in the coarse hand motor performance.

\section{REFERENCES}

1. Gemne G, Pyykkö I, Taylor W, Pelmear PL. The Stockholm Workshop scale for the classification of cold-induced Raynaud's phenomenon in the hand-arm vibration syndrome (revision of the Taylor-Pelmear scale). Scand J Work Environ Health 1987;13:275-8. doi: 10.5271/sjweh.2038

2. Heaver C, Goonetilleke KS, Ferguson H, Shiralkar S. Handarm vibration syndrome: a common occupational hazard in industrialized countries. J Hand Surg Eur Vol 2011;36:35463. doi: $10.1177 / 1753193410396636$

3. Harada N. Cold-stress tests involving finger skin temperature measurement for evaluation of vascular disorders in handarm vibration syndrome: review of the literature. Int Arch Occup Environ Health 2002;75:14-9. PMID: 11898872

4. Stoyneva Z, Lyapina M, Tzvetkov D, Vodenicharov E. Current pathophysiological views on vibration-induced Raynaud's phenomenon. Cardiovasc Res 2003;57:615-24. doi: 10.1016/S0008-6363(02)00728-9

5. ISO 14835-1: 2005. Mechanical vibration and shock - Cold provocation tests for the assessment of peripheral vascular function - Part 1: Measurement and evaluation of finger skin temperature. Geneva: International Organization for Standardization; 2005. 
6. Sakakibara H, Hirata M, Toibana N. Impaired manual dexterity and neuromuscular dysfunction in patients with hand-arm vibration syndrome. Ind Health 2005;43:542-7. PMID: 16100931

7. Toibana N, Ishikawa N, Sakakibara H. Measurement of manipulative dexterity in patients with hand-arm vibration syndrome. Int Arch Occup Environ Health 2002;75:106-10. PMID:11898869

8. Färkkilä M, Aatola S, Starck J, Korhonen O, Pyykko I. Handgrip force in lumberjacks: two-year follow-up. Int Arch Occup Environ Health 1986;58:203-8. PMID: 3770960

9. Necking LE, Lundborg G, Friden J. Hand muscle weakness in long-term vibration exposure. J Hand Surg Br 2002;27:5205. PMID: 12475507

10. Bovenzi M. A follow up study of vascular disorders in vibration-exposed forestry workers. Int Arch Occup Environ Health 2008;81:401-8. PMID: 17643261

11. Voelter-Mahlknecht S, Letzel S, Dupuis H. Diagnostic significance of cold provocation test at $12^{\circ} \mathrm{C}$. Environ Health Prev Med 2005;10:376-9. doi: 10.1007/BF02898200

12. Dupuis H, Riedel S. [Vibrationsbedingtes Vasospastisches Syndrom VVS (BK 2104), in German]. In: Letzel S, Nowak D, editor. Handbuch der Arbeitsmedizin. Landsberg: Ecomed; 2002. p. 1-13.

13. Ostman F, Lundborg G, Bornmyr S, Lilja B. Is vibrationinduced white finger a reversible syndrome if vibration is stopped? J Hand Surg Br 1996;21:750-2. PMID:8982916

14. Lander L, Lou W, House R. Nerve conduction studies and current perception thresholds in workers assessed for handarm vibration syndrome. Occup Med (Lond) 2007;57:284-9. doi: 10.1093/occmed/kqm012

15. Necking LE, Lundborg G, Lundstrom R, Thornell LE, Friden J. Hand muscle pathology after long-term vibration exposure. J Hand Surg Br 2004;29:431-7. PMID: 15336744

16. Lawson IJ, McGeoch KL. How likely is it that Stockholm stage 1 of the hand arm vibration syndrome will progress to stages 2 and 3? Occup Med (Lond) 1999;49:401-2. doi: 10.1093/occmed/49.6.401

17. ANSI S2.70-2006. American National Standard Guide for the measurement and evaluation of human exposure to vibration transmitted to the hand. Melville (NY): Acoustical Society of America; 2006

18. Bohannon RW, Peolsson A, Massy-Westropp N, Desrosiers J, Bear-Lehman J. Reference values for adult grip strength measured with a Jamar dynamometer: a descriptive meta analysis. Physiotherapy 2006;92:11-5. doi: 10.1016/j. physio.2005.05.003

19. Tiffin J, Asher EJ. The Purdue pegboard; norms and studies of reliability and validity. J Appl Psychol 1948;32:234-47. PMID:18867059

20. Holmér I. Extremity cooling and performance. In: Holmér I, editor. Work in cold environments. Helsinki: $\mathrm{NIOH} \&$ NIVA; 1994. p. 49-55.

21. Cederlund R, Iwarsson S, Lundborg G. Hand function tests and questions on hand symptoms as related to the Stockholm workshop scales for diagnosis of hand-arm vibration syndrome. J Hand Surg Br 2003;28:165-71. PMID: 12631491

22. Rui F, D’Agostin F, Negro C, Bovenzi M. A prospective cohort study of manipulative dexterity in vibration-exposed workers. Int Arch Occup Environ Health 2008;81:545-51. doi: 10.1007/s00420-007-0256-2

23. Goodwin AW, Wheat HE. Sensory signals in neural populations underlying tactile perception and manipulation. Annu Rev Neurosci 2004;27:53-77. doi: 10.1146/annurev. neuro.26.041002.131032

24. Johnson KO, Yoshioka T, Vega-Bermudez F. Tactile functions of mechanoreceptive afferents innervating the hand. J Clin Neurophysiol 2000;17:539-58. PMID: 11151974

25. Sakakibara H, Kondo T, Miyao M, Yamada S. Digital nerve conduction velocity as a sensitive indication of peripheral neuropathy in vibration syndrome. Am J Ind Med 1994;26:359-66. PMID: 7977409

26. Sakakibara H, Hirata M, Hashiguchi T, Toibana N, Koshiyama H, Zhu SK, Kondo T, Miyao M, Yamada S. Digital sensory nerve conduction velocity and vibration perception threshold in peripheral neurological test for handarm vibration syndrome. Am J Ind Med 1996;30:219-24. PMID: 8844053

27. Takeuchi T, Futatsuka M, Imanishi H, Yamada S. Pathological changes observed in the finger biopsy of patients with vibration-induced white finger. Scand J Work Environ Health 1986;12(4 Spec No):280-3. PMID: 3775312

28. Lundborg G, Dahlin LB, Danielsen N, Hansson HA, Necking LE, Pyykkö I. Intraneural edema following exposure to vibration. Scand J Work Environ Health 1987;13:326-9. PMID: 3433033

29. Takeuchi T, Takeya M, Imanishi H. Ultrastructural changes in peripheral nerves of the fingers of three vibration-exposed persons with Raynaud's phenomenon. Scand J Work Environ Health 1988;14:31-5. PMID: 3353694

30. Brammer AJ, Pyykkö I. Vibration-induced neuropathy. Detection by nerve conduction measurements. Scand J Work Environ Health 1987;13:317-22. PMID: 2829347

31. Cederlund R, Isacsson A, Lundborg G. Hand function in workers with hand-arm vibration syndrome. J Hand Ther 1999;12:16-24. PMID: 10192631

32. Necking LE, Dahlin LB, Friden J, Lundborg G, Lundstrom R, Thornell LE. Vibration-induced muscle injury. An experimental model and preliminary findings. J Hand Surg Br 1992;17:270-4. doi: 10.1016/0266-7681(92)90113-G

33. Strömberg T, Dahlin LB, Brun A, Lundborg G. Structural nerve changes at wrist level in workers exposed to vibration. Occup Environ Med 1997;54:307-11. PMID: 9196451

34. Lundborg G. Pain, nerve dysfunction and fatigue in a vibration-exposed population. Qual Life Res 1994;3(Suppl 1):S39-42. doi: 10.1007/BF00433375

35. Färkkilä M. Grip force in vibration disease. Scand J Work Environ Health 1978;4:159-66. PMID: 684389 


\section{Sažetak}

Procjena grube i fine motoričke funkcije šake u asimptomatičnih osoba izloženih vibracijama koje se prenose preko ruke i šake

U suvremenim uvjetima profesionalne izloženosti vibracijama koje se prenose preko ruke i šake, često se mogu vidjeti radnici koji su, i pored dugotrajne povremene izloženosti, i dalje bez uočljivih simptoma vibracijske bolesti. U većini dosadašnjih istraživanja analizirani su ispitanici s razvijenom kliničkom slikom vibracijske bolesti, uz rijetka razmatranja bioloških procesa koji mogu biti uključeni u degradaciju ručne spretnosti i snage stiska šake, osobito u asimptomatskoj fazi, kada bi to bilo od najveće koristi. U ovom su istraživanju uspoređene dvije skupine ispitanika: izložena skupina - 31 radnik izložen lokalnim vibracijama koji prema Stockholmskoj klasifikaciji nema simptome vibracijske bolesti, i kontrolna skupina - 30 radnika koji nisu izloženi lokalnim vibracijama. Svaki je ispitanik bio podvrgnut dinamometrijskom i deksterimetrijskom testiranju (model za grubu i finu motoričku funkciju šake) te testu provokacije hladnoćom radi usporedbe pada motoričkih funkcija šake. U izloženoj skupini zabilježen je pad fine motoričke funkcije, ali ne i snage stiska šake. Rezultati upozoravaju na mjerljiv deficit grube ali ne i fine motoričke funkcije šake kod povremene izloženosti s malim kumulativnim dozama, čak i kada se radi o dugotrajnoj izloženosti nezanemarivim razinama A(8). Vibracijama inducirane lezije živčanih vlakana i/ ili mehanoreceptora, koji osiguravaju senzornu povratnu vezu za signale pokreta - čime kontroliraju zadatke koji iziskuju precizno kretanje prstiju - mogle bi biti odgovorne za uočeno smanjenje ručne spretnosti. Taj mehanizam, međutim, nije potreban za kontrolu grube sile stiska.

KLJUČNE RIJEČI: izloženost vibracijama; provokacija hladnoćom; ručna spretnost; snaga stiska šake

\section{CORRESPONDING AUTHOR:}

Martin Popević, MD, MSc

Serbian Institute for Occupational Health

Deligradska 29

11000 Belgrade, Serbia

E-mail:popevic.martin@gmail.com,martin_popevic@med.bg.ac.rs 